\title{
Modulation of Sirt1 by resveratrol and nicotinamide alters proliferation and differentiation of pig preadipocytes
}

\author{
Liang Bai · Wei-Jun Pang · Yan-Jun Yang • \\ Gong-She Yang
}

Received: 27 May 2007/Accepted: 23 August 2007/Published online: 13 September 2007

(c) Springer Science+Business Media, LLC 2007

\begin{abstract}
Sirt1, a NAD ${ }^{+}$-dependent histone deacetylase, may regulate senescence, metabolism, and apoptosis. In this study, primary pig preadipocytes were cultured in DMEM/F12 medium containing 10\% fetal bovine serum (FBS) with or without reagents affecting Sirt1 activity. The adipocyte differentiation process was visualized by light microscopy after Oil red $\mathrm{O}$ staining. Proliferation and differentiation of preadipocytes was measured using methylthiazolyldiphenyl-tetrazolium bromide (MTT) and Oil red $\mathrm{O}$ extraction. Expression of Sirt1, FoxO1, and adipocyte specific genes was detected with semi-quantitive RT-PCR. The results showed that Sirt1 mRNA was widely expressed in various pig tissues from different developmental stages. Sirt1 mRNA was expressed throughout the entire differentiation process of pig preadipocytes. Resveratrol significantly increased Sirt1 mRNA expression, but decreased the expression of FoxO1 and adipocyte marker gene PPAR $\gamma 2$. Resveratrol significantly inhibited pig preadipocyte proliferation and differentiation. Nicotinamide decreased the expression of Sirt1 mRNA, but increased the expression of FoxO1 and adipocyte specific genes. Nicotinamide greatly stimulated the proliferation and differentiation of pig preadipocytes. In conclusion, these results indicate that Sirt1 may modulate the proliferation and differentiation of pig preadipocytes. Sirt1 may down-regulate pig preadipocytes proliferation and differentiation through repression of adipocyte genes or FoxO1.
\end{abstract}

L. Bai · W.-J. Pang · Y.-J. Yang · G.-S. Yang $(\bowtie)$

Laboratory of Animal Fat Deposition and Muscle Development,

College of Animal Science and Technology, Northwest A\&F

University, 22 Xinong Road, Yangling, Shaanxi Province

712100, P.R. China

e-mail: gsyang999@hotmail.com
Keywords Sirt1 - FoxO1 - Adipocyte genes · Pig · Preadipocyte $\cdot$ Proliferation $\cdot$ Differentiation

\section{Introduction}

Adipocyte is an important mediator in many physiologic and pathologic processes regarding energy metabolism [1]. Change in adipocyte number is achieved through a complex interplay between proliferation and differentiation of preadipocytes [2]. It is a highly controlled process under the influence of various hormones, cytokines and nutrients, and exerts pleiotropic (including endocrine) functions [3]. Once dysregulation of adipocyte proliferation and differentiation, it causes obesity, lipoatrophy [2], cardiovascular disease, noninsulin-dependent diabetes mellitus [1], and a decrease in animal meat quality. Thus, the study on adipocyte development has become an area of intense research in recent years.

The silent information regulator 2 (Sir2) is a highly conserved nicotinamide adenine dinucleotide (NAD)-dependent histone deacetylase that has been shown to modulate organism life span in many species $[4,5]$. In mammals, there are seven members of the Sir2 family, termed sirtuins (SIRTs), among which Sirt1 is the closest homolog of yeast Sir2 protein [6, 7]. Sirt1 is primarily located in the nucleus and shares the catalytic domain with Sir2 [8]. In addition to histone, Sirt1 also deacetylates other proteins, including Forkhead transcription factors FOXO, MyoD, and the tumor suppressor p53, PGC-1 $\alpha$ [9-14]. Thus, Sirt1 can monitor cellular metabolism and exert corresponding effects on gene expression. The phenotype of $\operatorname{sir} 2 \alpha$ null animals suggests that the SIR $2 \alpha$ protein is essential for normal embryogenesis and for normal reproduction in both sexes [15]. Several studies showed that Sirt1 is a key regulator of cell defenses 
and survival in response to stress $[9,10]$. Luo et al. reported that human Sirt1 represses p53-dependent apoptosis in response to DNA damage and oxidative stress [12]. Meanwhile, Sirt1 deacetylates and represses FoxO1-dependent apoptosis [9]. Brunet et al. found that Sirt1 increases the ability of FOXO3 to induce cell cycle arrest and resistance to oxidative stress, but inhibited the ability of FOXO3 to induce cell death [10]. In addition, Sirt1 can promote fat mobilization in white adipocytes by repressing PPAR- $\gamma$ [16]. Activation of Sirt1 decreases adipocyte formation during osteoblast differentiation of mesenchymal stem cells [17]. It was recently hypothesized that Sirt 1 might be a candidate linking reduced adiposity to lifespan [18]. In pancreatic $\beta$ cells, Sirt1 promotes insulin secretion and improves content of blood glucose by repressing UCP2, which implies that activation of Sirt1 is helpful for therapy of type 2 diabetes [19]. Thus, scientists proposed that Sirt1 might be a target protein to prevent and control human obesity and related diseases [20, 21]. Due to its important relationship with cell development, senescence, apoptosis, and metabolism, Sirt1 has been the subject of many research studies in recent years.

Animal models of human diseases have always played a central role in biomedical research for the exploration and development of new therapies. Compared with other animal models (e.g., mouse and rabbit), pig models offer many advantages including close similarity to human physiological characteristic (cardiovascular anatomy and function, metabolism, lipoprotein profile, size, tendency to obesity), genetic modulation of growth and fat deposition, and pathologic reaction response to high-energy intake [22-24]. Similar results have also been found in the Guinea pig [25]. Fernandez reported that Guinea pig could be as models to study hepatic cholesterol and lipoprotein metabolism [25]. In addition, miniature pig can successfully be applied to research in reproduction, transgenesis, epidermal, and neural stem cell [26]. Therefore, pigs are the optimal model animals in biomedical research.

We found rarely reports about pig Sirt1 in the literature. The existence of Sirt1 in pigs and its role in adipocyte development is unknown at present. Therefore, this article will focus on the expression of Sirt1 in pigs and its effect on the proliferation and differentiation of pig preadipocytes. The results of this study will provide important information regarding the control of fat deposition in pigs as well as biomedical research.

\section{Materials and methods}

\section{Reagents}

Resveratrol, nicotinamide, and Oil red $\mathrm{O}$ were purchased from Sigma (America). DMEM/F12 and collagenase (type
I ) were purchased from Gibco (America). Fetal bovine serum (FBS) was obtained from Hangzhou Sijiqing Biological Engineering Materials Co., Ltd. (Hangzhou, China). Methylthiazolyldiphenyl-tetrazolium bromide (MTT) was bought from Beyotime Biotechnology Inst (China). TRIzol Reagent was obtained from BioTeke Biotechnologies Inc. (Beijing, China). Both RevertAid ${ }^{\mathrm{TM}}$ First Strand cDNA Synthesis Kit and Taq DNA Polymerase were bought from MBI Fermentas. dNTP was purchased from TaKaRa Biotechnology (Dalian, China) Co., Ltd. The primers of Sirt1, FoxO1, PPAR $\gamma 2, \operatorname{CEBP} \alpha$, aP2, and LPL were synthesized by Shanghai Sangon Biological Engineering Technology \& Services Co., Ltd. (Shanghai, China).

\section{Collection of animal tissue samples}

Ten healthy male crossbred (Duroc $\times$ Seghers) piglets (3-day-old) and ten male crossbred (Duroc $\times$ Seghers) adult pigs (180-day-old) were provided by the Northwest A\&F University experiment farm and Ge Runer Bright Livestock Company (Yangling, China). All pigs were handled in accordance with the guidelines of Northwest A\&F University Animal Care Committee. Heart, liver, lung, kidney, muscle, subcutaneous adipose and visceral adipose were isolated, collected, quickly frozen in liquid nitrogen, and stored at $-70^{\circ} \mathrm{C}$ for later use.

Pig primary preadipocytes in vitro culture

Subcutaneous adipose tissue was collected from the neck and back of the piglets and rinsed with serum-free medium (DMEM/F12 medium supplemented with $15 \mathrm{mM}$ $\mathrm{NaHCO}_{3}, 50 \mathrm{U}$ penicillin/ml and streptomycin). The tissue mass was cut with scissors into approximately $1 \mathrm{~mm}^{3}$ sections under sterile-free condition and digested with type I collagenase (DMEM/F12 + $20 \mathrm{~g} / 1 \mathrm{BSA}+1 \mathrm{~g} / 1 \mathrm{I}$ type collagenase) for about $60-90 \mathrm{~min}$ at $37^{\circ} \mathrm{C}$ in a shaking water bath. Then, DMEM/F12 medium containing $10 \%$ FBS was added to stop digestion. The solution was passed through $200-\mu \mathrm{m}$ nylon filters to remove undigested tissue and large cell aggregates and then centrifuged at 2,000 rpm for 5 min to separate the floating adipocytes from the pellet of stromal-vascular cells. The pellet was washed twice with serum-free medium. After washing, stromal-vascular cells were resuspended in DMEM/F12 medium containing 10\% FBS and counted with hemacytometry. Finally, cells were seeded in culture plates at a density of $5 \times 10^{4}$ cells $/ \mathrm{cm}^{2}$ and cultured at $37^{\circ} \mathrm{C}$ in a humidified atmosphere containing $5 \% \mathrm{CO}_{2}$. The medium was changed every second day. 
MTT method

Methylthiazolyldiphenyl-tetrazolium bromide $(5 \mathrm{mg} / \mathrm{ml})$ was dissolved in PBS (0.01 M, PH 7.4) and stirred in constant temperature magnetic stirrer for $30 \mathrm{~min}$. Then, it was passed through $0.22-\mu \mathrm{m}$ microfiltration membrane to remove bacteria and kept for no more than 2 weeks at $4^{\circ} \mathrm{C}$. Preadipocytes were seeded in 96 -well culture plates at a density of $10^{4} / \mathrm{cm}^{2}$ and then 200- $\mu$ DMEM/F12 medium containing $10 \%$ FBS was added to each well. Resveratrol of $0 \mu \mathrm{M}, 10 \mu \mathrm{M}, 20 \mu \mathrm{M}, 50 \mu \mathrm{M}, 100 \mu \mathrm{M}$, and nicotinamide of $0 \mu \mathrm{M}, 100 \mu \mathrm{M}, 200 \mu \mathrm{M}, 300 \mu \mathrm{M}, 400 \mu \mathrm{M}$, $500 \mu \mathrm{M}$ were added to medium when cells were cultured for $24 \mathrm{~h}$. After the specific time, one cell culture plate was taken out for MTT. We added $20 \mu \mathrm{l}$ MTT reagents to each well and then cultured the cells for $4 \mathrm{~h}$. Afterwards, the medium was removed and $150 \mu \mathrm{DMSO}$ was added to each well to dissolve formazan. The 96-well culture plate was agitated for $10 \mathrm{~min}$ on a shaker. Finally, a well with DMSO but without cells was used to adjust zero and the OD value of each well was detected at $490 \mathrm{~nm}$ by type of DG5031 ELISA Reader (Medical Equipment Co., Ltd., Huadong Electronics Group, Nanjing, China).

\section{Oil red $\mathrm{O}$ staining}

Preadipocytes were seeded in 24-well culture plates at a density of $5 \times 10^{4} / \mathrm{cm}^{2}$. Resveratrol of $0 \mu \mathrm{M}, 10 \mu \mathrm{M}$, $20 \mu \mathrm{M}, 50 \mu \mathrm{M}, 100 \mu \mathrm{M}$, and nicotinamide of $0 \mu \mathrm{M}$, $100 \mu \mathrm{M}, 200 \mu \mathrm{M}, 300 \mu \mathrm{M}, 400 \mu \mathrm{M}, 500 \mu \mathrm{M}$ were added to medium when cells were confluent and began to differentiate. After the specific time, cell culture plates for Oil red $\mathrm{O}$ staining were taken out and the medium was removed. Cells were washed three times with PBS and fixed with $10 \%$ formaldehyde for $30 \mathrm{~min}$ at room temperature. After washing three times with PBS, cells were stained with $1 \%$ filtered Oil red $\mathrm{O}$ for $8 \mathrm{~min}$ at room temperature. Then, Oil red $\mathrm{O}$ solution was removed and the cells were immediately destained with $60 \%$ isopropanol solution for 10-20 s. Finally, the nuclei were restained with hematoxylin for $1 \mathrm{~min}$ and cells were gently washed with tap water. Red stained adipocytes were examined with light microscopy.

\section{Oil red $\mathrm{O}$ extraction}

The steps for Oil red $\mathrm{O}$ extraction were similar to the described above for Oil red $\mathrm{O}$ staining. Cells were washed three times with PBS and fixed with $10 \%$ formaldehyde for $30 \mathrm{~min}$ at room temperature. After washing with PBS three times, the cells were stained with $1 \%$ filtered Oil red $\mathrm{O}$ for $40 \mathrm{~min}$ at room temperature. Then, Oil red $\mathrm{O}$ solution was removed and the cells did not need to be washed. Intracellular triglyceride levels in the cells were agitatedly extracted with $100 \%$ isopropanol solution of $2,000 \mu \mathrm{l}$ for 15 min in Shaker. Finally, a hole with DMSO was used to adjust zero and OD value of each hole was detected in $500 \mathrm{~nm}$ using type of UV-2102 PC ultraviolet spectrophotometer (Unico Instrument Co., Ltd., Shanghai, China).

\section{RT-PCR analysis}

Total RNA was extracted from different tissues with Trizol Reagent. According to method recommended by Fermentas RevertAid $^{\mathrm{TM}}$ First Strand cDNA Synthesis Kit \#K1621,

Table 1 The specific primers for genes in polymerase chain reaction

\begin{tabular}{|c|c|c|c|c|}
\hline Genes & Primers $\left(5^{\prime}-3^{\prime}\right)$ & Product sizes (bp) & Annealing temperature $\left({ }^{\circ} \mathrm{C}\right)$ & Cycle times \\
\hline Sirt1 & $\begin{array}{l}\text { S: GAACAGGTTGCGGGAATC } \\
\text { A: AACATGAAGAGGTGTGGGTG }\end{array}$ & 553 & 53.5 & 30 \\
\hline FoxO1 & $\begin{array}{l}\text { S: GCCGTGCTACTCGTTTGC } \\
\text { A: CTTGGGTCAGGCGGTTC }\end{array}$ & 467 & 54.1 & 30 \\
\hline $\operatorname{PPAR} \gamma 2$ & $\begin{array}{l}\text { S: AGACCCAGAAAGCGATGC } \\
\text { A: CCTGATGGCGTCGTTATGAGACA }\end{array}$ & 595 & 56.1 & 30 \\
\hline $\mathrm{C} / \mathrm{EBP} \alpha$ & $\begin{array}{l}\text { S: GGTGGACAAGAACAGCAACG } \\
\text { A: AGGCACCGGAATCTCCTAGT }\end{array}$ & 388 & 54.3 & 28 \\
\hline $\mathrm{aP} 2$ & $\begin{array}{l}\text { S: GACAGGAAAGTCAAGAGCACC } \\
\text { A: GGGACAATACATCCAACAGAG }\end{array}$ & 226 & 53.2 & 28 \\
\hline LPL & $\begin{array}{l}\text { S: AACTTGTGGCTGCCCTAT } \\
\text { A: TGACCCTCTGGTGAATGTG }\end{array}$ & 368 & 52 & 28 \\
\hline$\beta$-actin & $\begin{array}{l}\text { S: ACTGCCGCATCCTCTTCCTC } \\
\text { A: CTCCTGCTTGCTGATCCACATC }\end{array}$ & 399 & 56.8 & 26 \\
\hline
\end{tabular}


First cDNA strand was synthesized and the final volume was $20 \mu \mathrm{l}$, including $5 \mu \mathrm{l}$ total RNA, random hexamer primer $1 \mu \mathrm{l}$, DEPC-treated water $6 \mu \mathrm{l}, 5 \times$ reaction buffer $4 \mu \mathrm{l}$, RiboLock ${ }^{\mathrm{TM}}$ Ribonuclease Inhibitor $(20 \mathrm{U} / \mu \mathrm{l}) 1 \mu \mathrm{l}$, $10 \mathrm{mM}$ dNTP mix $2 \mu \mathrm{l}$, RevertAid ${ }^{\mathrm{TM}}$ M-MuLV Reverse Transcriptase $(200 \mathrm{U} / \mu \mathrm{l}) 1 \mu \mathrm{l}$. All PCR primers were designed using Primer 5.0 Software (Table 1), among which the PCR primer for Sirt1 was designed according to the human Sirt1 gene sequence (NM_012238) from GenBank. $\beta$-actin was determined as a control for loading. PCR system was $25 \mu \mathrm{l}$, containing $15.75 \mu \mathrm{l}$ sterile, dI water, $2.5 \mathrm{mmol} / \mathrm{l}$ dNTP Mix of $2 \mu \mathrm{l}, 2.5$ - $\mu \mathrm{l}$ PCR buffer $(\mathrm{NH})_{2} \mathrm{SO}_{4}, 25 \mathrm{mmol} / \mathrm{l} \mathrm{MgCl}_{2}$ of $1.5 \mu \mathrm{l}$, cDNA of $1 \mu \mathrm{l}$, $25 \mu \mathrm{mol} / \mathrm{l}$ Primer I of $0.5 \mu \mathrm{l}, 25 \mu \mathrm{mol} / \mathrm{l}$ Primer II of $0.5 \mu \mathrm{l}$, $0.5 \mathrm{U} / \mu \mathrm{l}$ Taq DNA Polymerase of $1.25 \mu \mathrm{l}$. PCR condition was as follows: $95^{\circ} \mathrm{C} 6 \mathrm{~min}, 94^{\circ} \mathrm{C} 45 \mathrm{~s}, 50-60^{\circ} \mathrm{C} 1 \mathrm{~min}$, $72^{\circ} \mathrm{C} 1 \mathrm{~min}, 26-30$ cycle, $72^{\circ} \mathrm{C} 10 \mathrm{~min}, 4^{\circ} \mathrm{C} 10 \mathrm{~min}$. PCR amplification was performed in PTC-200 DNA engine. After mixture of $2.5 \mu \mathrm{l} \mathrm{PCR}$ product with a little of bromophenol blue, $1 \%$ agarose gel electrophoresis contained EB was proceeded. Meanwhile, DNA Marker 2000 was added to determine the size of product band. The electrophoresis bands were taken photo using Wealtec Gel Image Formation System and analyzed by Dophin-1D Gel Analysis software.

\section{Statistical analysis}

All data were obtained from one independent experiment carried out in triplicate. Main and interactive effects were analyzed by One-Way ANOVA using SPSS11.5 software. When justified by One-Way ANOVA, differences between individual group means were analyzed by Fisher's PLSD test. Differences were considered statistically significant at $P<0.05$.

\section{Results}

Expression of Sirt1 mRNA in various pig tissues at different developmental stages

The Sirt1 cDNA sequence of pigs has not been reported. In order to confirm the existence and expression profile of Sirt1 in pigs, a specific primer for Sirt1 was designed based on the human Sirt1 gene sequence (NM_012238) from GenBank. The partial cDNA sequence of Sirt1 (530 bp) in pig was cloned and GenBank number was DQ868430. Clustal W software analysis showed that Sirt1 had 94\%, $90 \%, 88 \%$ homolog with human, rat, and mouse (Data was not shown). Total RNA was extracted from the heart, liver, lung, kidney, spleen, muscle, subcutaneous adipose and

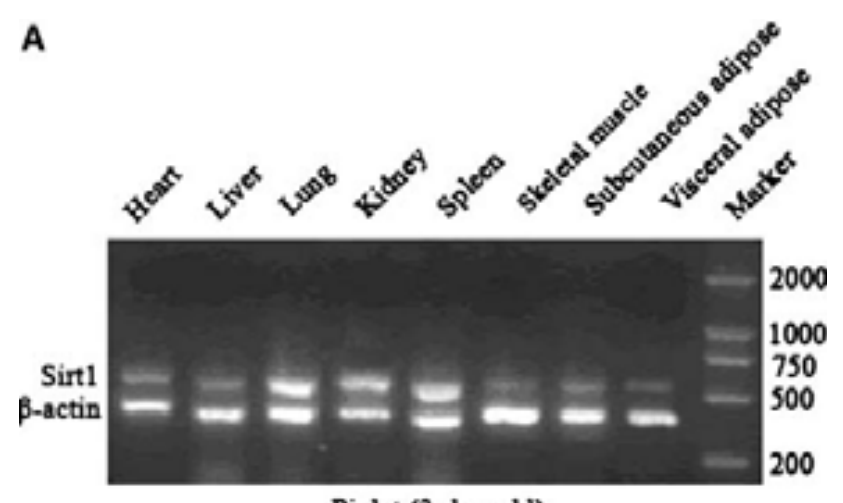

Piglet (3-dny-old)

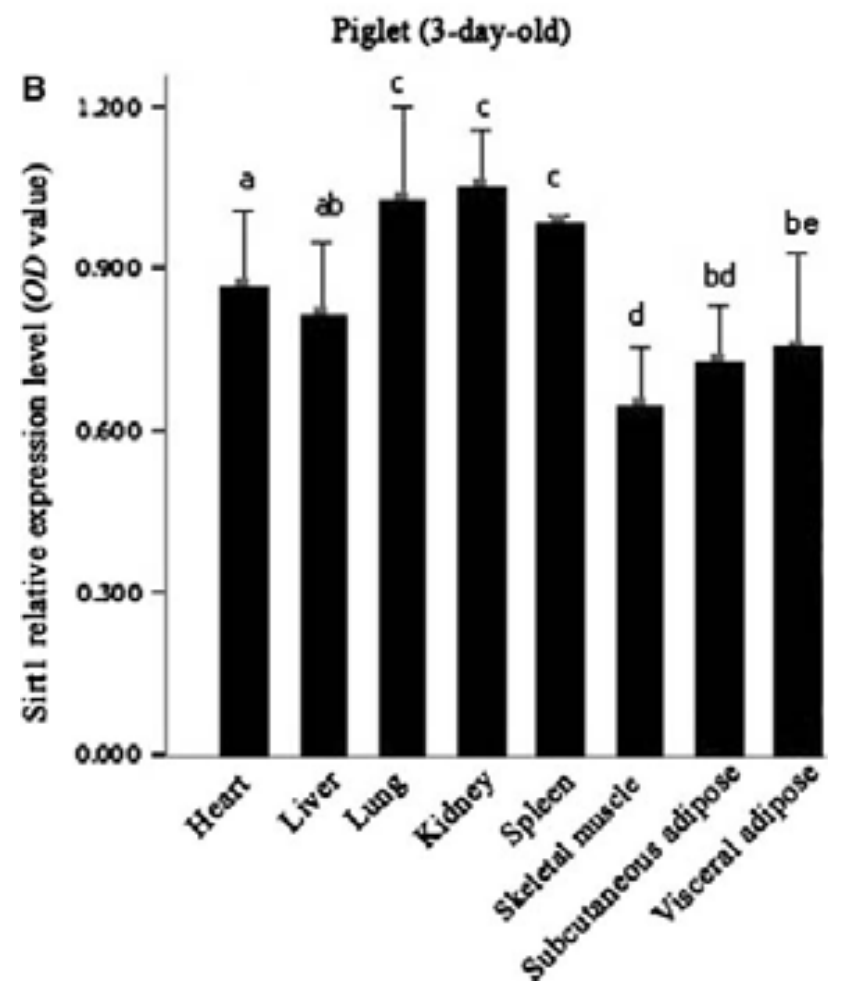

Fig. 1 Expression of Sirt1 in different tissues from 3-day-old pigs. Total RNA of various tissues was isolated and subjected to SQ RTPCR analysis. (A) Representative ethidium bromide stained gels of target products as well as $\beta$-actin in the same sample. (B) Sirt1 mRNA abundance assigned as a ratio to $\beta$-actin mRNA. The results are represented as means \pm S.E. of three independent determinations. Different letters indicate significantly differences $(P<0.05)$

visceral adipose of piglets and adult pigs. Sirt1 mRNA expression was detected by RT-PCR. The electrophoresis bands of Sirt 1 and $\beta$-actin were changed into OD value by Dophin DOC data change system. The ratio of Sirt1 and $\beta$-actin OD value was termed as Sirt1 relative mRNA expression. Analysis indicated Sirt 1 mRNA was widely expressed in the heart, liver, lung, kidney, spleen, muscle, subcutaneous and visceral adipose of piglets and adult pigs (Figs. 1A and 2A). For piglets, Sirt1 mRNA was most 


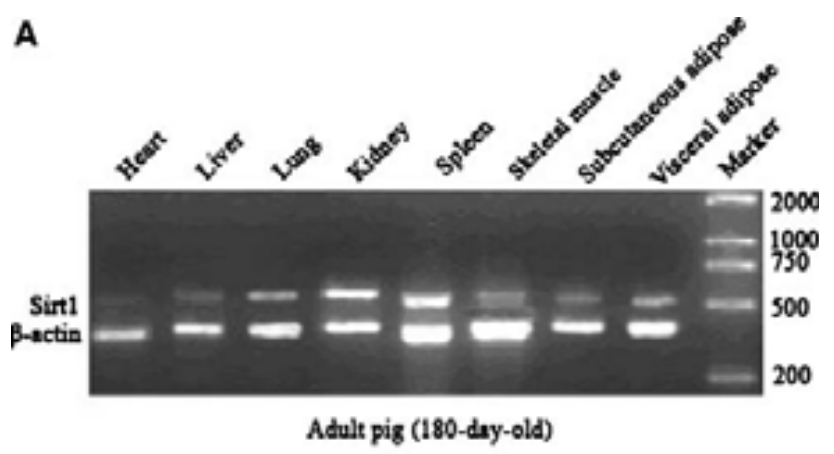

Adult pig (180-day-old)

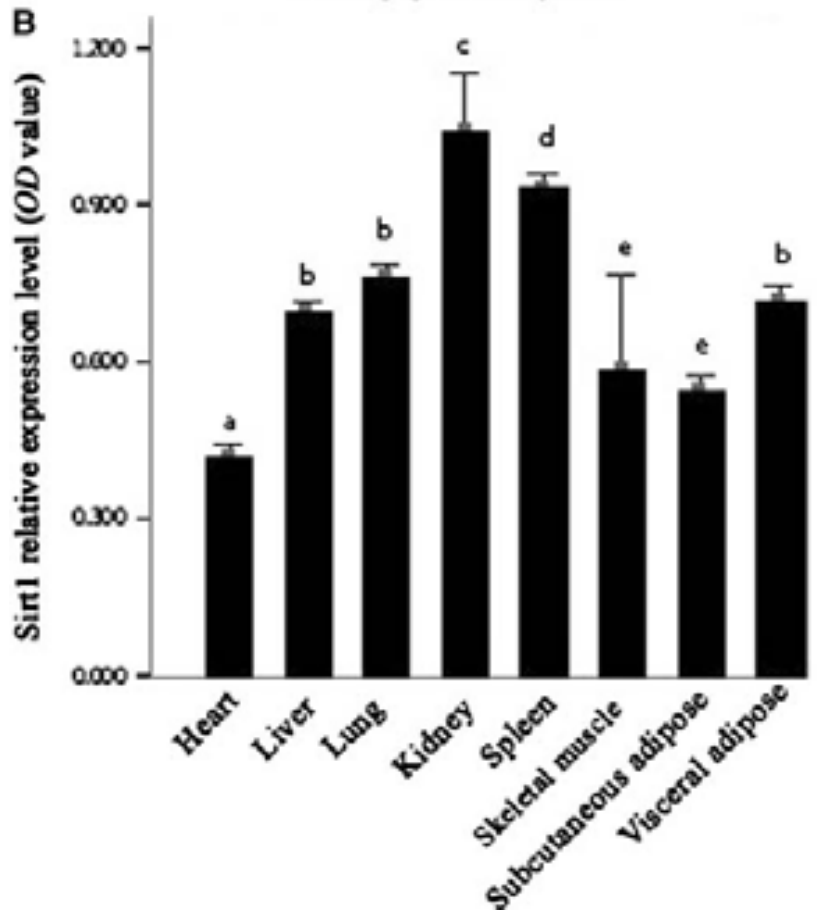

Fig. 2 Expression of Sirt1 in different tissues from 180-day-old pigs. Total RNA of various tissues was isolated and subjected to SQ RTPCR analysis. (A) Representative ethidium bromide stained gels of target products as well as $\beta$-actin in the same sample. (B) Sirt1 mRNA abundance assigned as a ratio to $\beta$-actin mRNA. The results are represented as means \pm S.E. of three independent determinations. Different letters indicate significantly differences $(P<0.05)$

abundant in lung, kidney and spleen tissue and least abundant in skeletal muscle and subcutaneous adipose (Fig. 1B). For adult pigs, Sirt1 mRNA was highly expressed in kidney and spleen tissue, and least expressed in heart tissue. Furthermore, Sirt1 mRNA expression was significantly different between subcutaneous adipose and visceral adipose $(P<0.05)$ (Fig. 2B). This suggested that Sirt1 is not only existed in pig but also widely expressed in various tissues from pigs of different developmental stages, speculating that Sirt1 may be involved in multiple activities in pig and exerts different effects in various tissues.
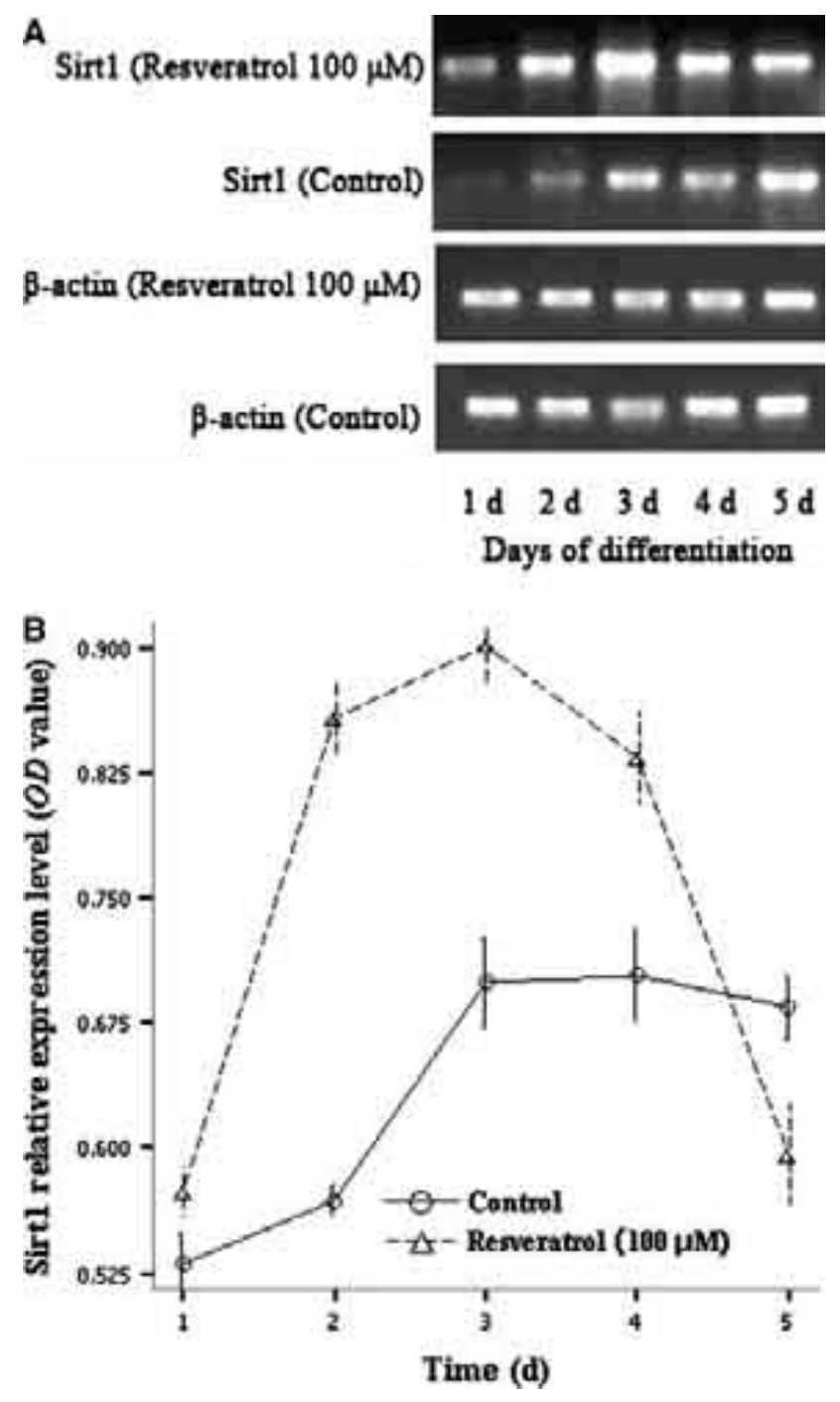

Fig. 3 The time-spatial expression of Sirt1 in pig adipocytes. Preadipocytes were treated with or without $100 \mu \mathrm{M}$ resveratrol for $1,2,3,4$, or 5 days. Total RNA was isolated and subjected to SQ RTPCR analysis. (A) Representative ethidium bromide stained gels of target products as well as $\beta$-actin in the same sample. (B) Sirt1 mRNA abundance assigned as a ratio to $\beta$-actin mRNA. The results are represented as means \pm S.E. of three independent determinations

Time-spatial expression of Sirt1 mRNA during adipocyte differentiation in pig

After confirming the existence of Sirt1 in pig adipose, we next investigated the time-spatial expression of Sirt1 mRNA in pig adipocytes under normal and stimulated conditions. Resveratrol, a polyphenol found in red wine, was chosen as an activator of Sirt1 [27]. When preadipocyte density reached to nearly $80 \%, 100 \mu \mathrm{M}$ resveratrol was added to the medium and cultured for 1, 2, 3, 4, or 5 days. RT-PCR analysis indicated that Sirt 1 mRNA was expressed in preadipocytes before and after differentiation (Fig. 3A). Under normal conditions, the expression of Sirt1 

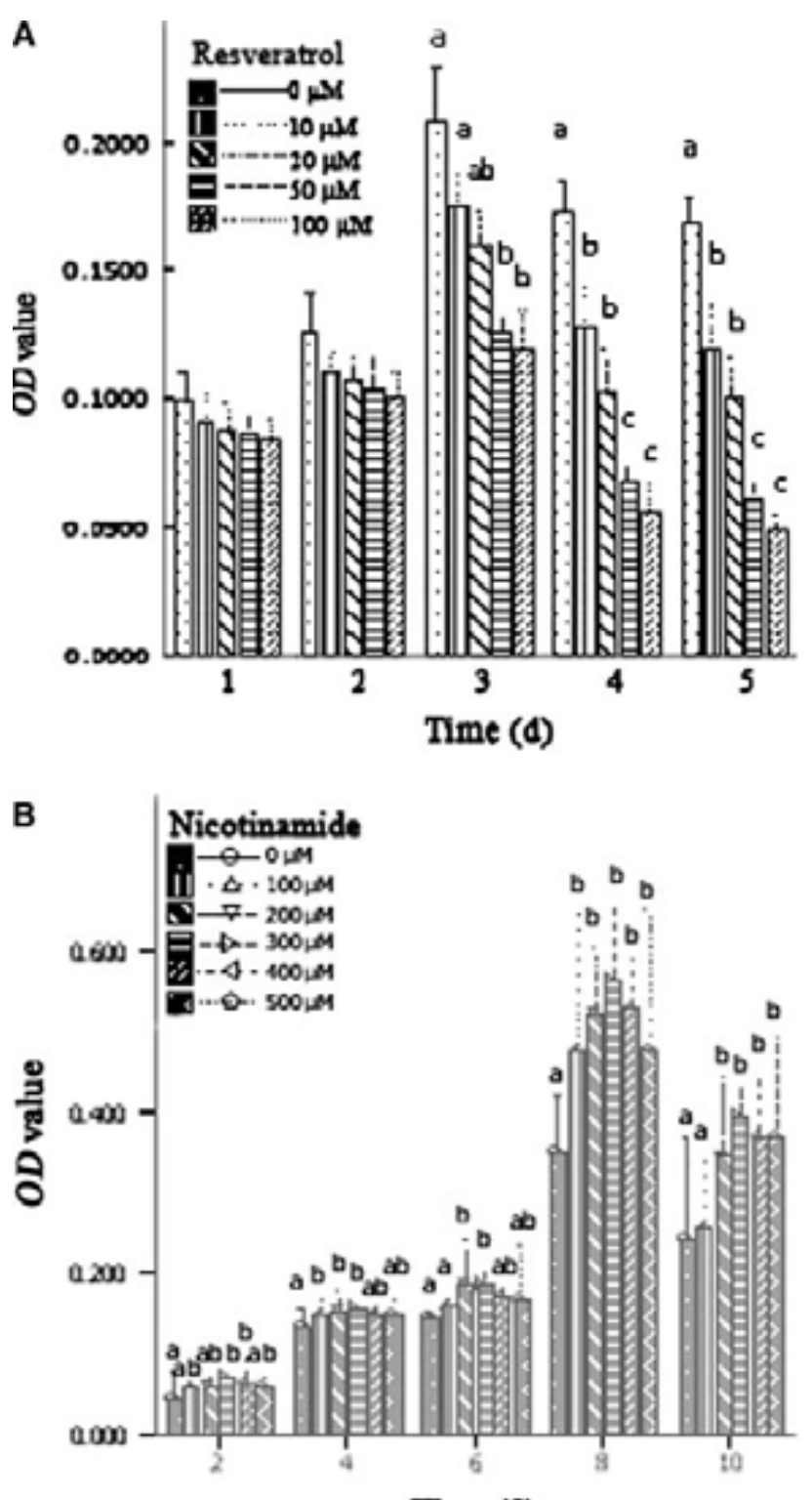

Time (d)

Fig. 4 Pig preadipocytes were treated with $0 \mu \mathrm{M}, 10 \mu \mathrm{M}, 20 \mu \mathrm{M}$, $50 \mu \mathrm{M}$, and $100 \mu \mathrm{M}$ resveratrol or $0 \mu \mathrm{M}, 100 \mu \mathrm{M}, 200 \mu \mathrm{M}, 300 \mu \mathrm{M}$, $400 \mu \mathrm{M}$, and $500 \mu \mathrm{M}$ nicotinamide for different days, and then analyzed with MTT to test the effect of these chemicals on the proliferation of pig preadipocytes. The results are represented as means \pm S.E. of three independent determinations. Different letters indicate significant differences $(P<0.05)$

mRNA gradually increased, reached a peak at 4 days after differentiation, and then declined steadily. Resveratrol stimulation had a significant effect on Sirt1 mRNA expression. Specifically, Sirt1 mRNA expression in the resveratrol treatment was significantly higher than normal group 2 and 3 days after differentiation $(P<0.01)$. Sirt 1 mRNA expression in the resveratrol-treated adipocytes peaked at 3 days after differentiation and then declined significantly (Fig. 3B). On day 5 after differentiation, Sirt1
mRNA expression was lower than the normal group, mainly due to cell apoptosis or death of adipocytes which occurred after extended treatment with resveratrol. These results indicated that Sirt1 mRNA expression was highest at the middle stage of adipocyte differentiation and could be strongly activated by resveratrol. This suggests that Sirt1 may be involved in adipocyte development.

Effects of compounds regulating Sirt1 activity on the proliferation of pig preadipocytes

Methylthiazolyldiphenyl-tetrazolium bromide, a simple, quick, and accurate method to detect cell viability, has been widely used to check cell proliferation and multiple biological medicines. In this study, resveratrol was used as an activator and nicotinamide was used as an inhibitor of the Sirt1 protein. To study how Sirt1 influenced the proliferation of pig preadipocytes, resveratrol $(0 \mu \mathrm{M}, 10 \mu \mathrm{M}$, $20 \mu \mathrm{M}, 50 \mu \mathrm{M}$, and $100 \mu \mathrm{M})$ and nicotinamide $(0 \mu \mathrm{M}$, $100 \mu \mathrm{M}, 200 \mu \mathrm{M}, 300 \mu \mathrm{M}, 400 \mu \mathrm{M}, 500 \mu \mathrm{M})$ were added to medium. Cells were detected by MTT method at the specific time. Under resveratrol stimulation, the OD value of each treated group was lower than control group. Preadipocyte proliferation was significantly reduced in the 50- and $100-\mu \mathrm{M}$ resveratrol treatments at day 4 and 5 $(P<0.01)$ (Fig. 4A). This indicated that high concentrations of resveratrol over a long period could inhibit the proliferation of pig preadipocytes. In contrast to resveratrol, OD values were higher in the nicotinamide treatment compared to the control. Preadipocyte proliferation in the $300 \mu \mathrm{M}$ nicotinamide was significantly higher at different treatment time $(P<0.01)$ (Fig. 4B). These results showed that nicotinamide could promote proliferation of pig preadipocytes. The above findings strongly suggested that compounds affecting Sirt1 activation influenced pig preadipocyte proliferation during the adipogenesis process.

Effects of compounds affecting Sirt1 activity on the differentiation of pig preadipocytes

Adipogenesis is a highly regulatory process. Preadipocyte proliferation and differentiation into mature adipocytes occur in a series of stages. We were interested to determine if agents known to regulate Sirt1 activity could influence pig preadipocyte differentiation in vitro. Thus we treated preadipocytes with resveratrol and nicotinamide at differentiation and then cultured the cells. Afterward, the cells were stained with Oil red $\mathrm{O}$ and the size and number of adipocytes were determined visually by light microscope.

Through Oil red $\mathrm{O}$ staining, we could see that preadipocytes in the control group differentiated into mature 
Fig. 5 Effects of resveratrol on pig preadipocyte differentiation. Predipocytes were treated with $0 \mu \mathrm{M}, 10 \mu \mathrm{M}, 50 \mu \mathrm{M}$, and $100 \mu \mathrm{M}$ resveratrol for 4 days, and then visualized by Oil red $\mathrm{O}$ staining $(\times 200)$. Lipid droplets were stained bright red.

(A) Control group; (B) $10 \mu \mathrm{M}$ resveratrol; (C) $50 \mu \mathrm{M}$ resveratrol; (D) $100 \mu \mathrm{M}$ resveratrol
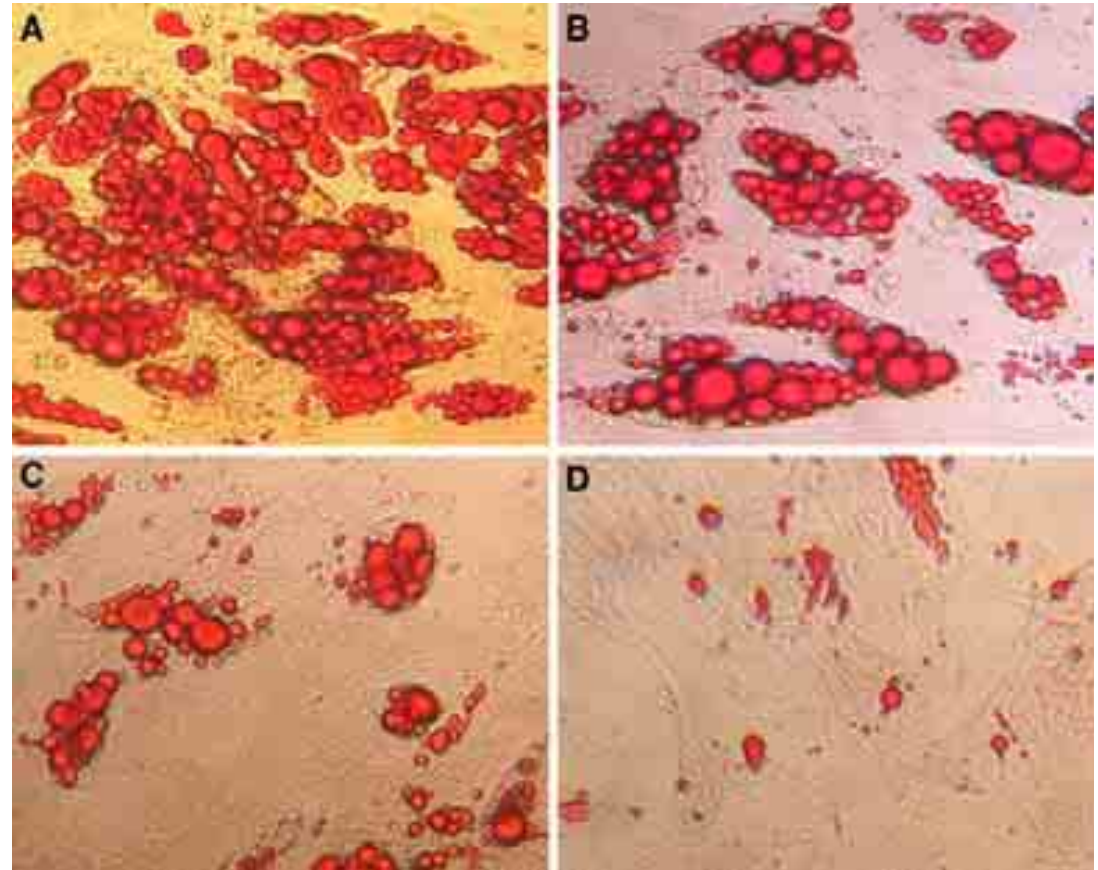

adipocytes, which were large, round, and filled with fat droplets. In comparison, there were significantly fewer fat droplets in adipocytes in the 50- and $100-\mu \mathrm{M}$ resveratrol treatments. Both the size and number of fat cells decreased in the resveratrol treatment compared to the control (Fig. 5). Results from Oil red O extraction showed that TG

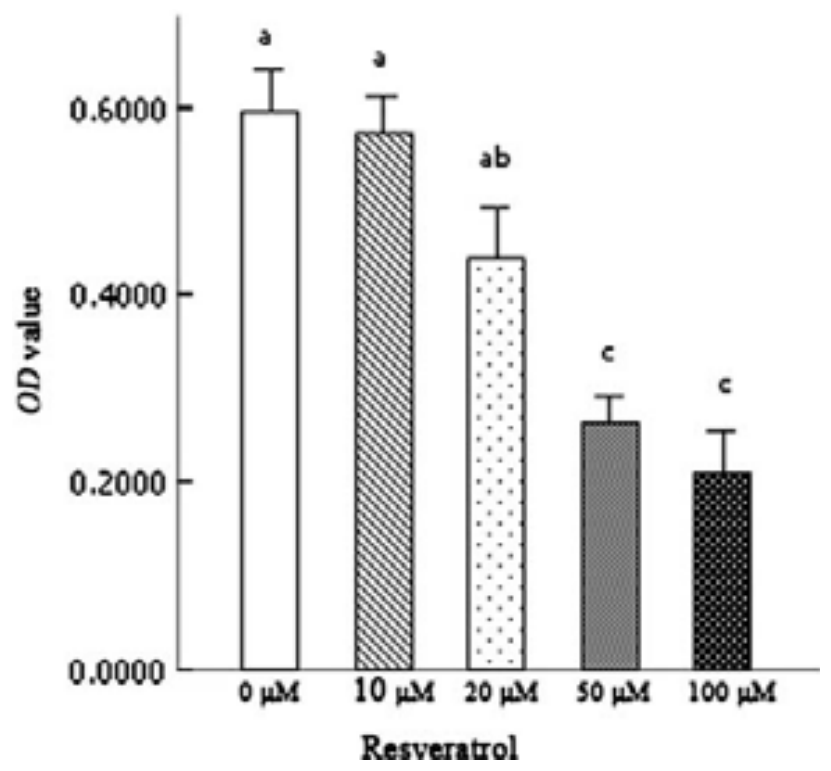

Fig. 6 Pig preadipocyte differentiation was inhibited by resveratrol. Predipocytes were treated with $0 \mu \mathrm{M}, 10 \mu \mathrm{M}, 20 \mu \mathrm{M}, 50 \mu \mathrm{M}$, and $100 \mu \mathrm{M}$ resveratrol for 4 days, and then analyzed by Oil red $\mathrm{O}$ extraction. The results are represented as means \pm S.E. of three independent determinations. Different letters indicated significant differences $(P<0.05)$ content notably decreased in the 50- and $100-\mu \mathrm{M}$ resveratrol treatments compared to the control and $10-\mu \mathrm{M}$ resveratrol treatments $(P<0.01)$ (Fig. 6). This suggested that high resveratrol concentrations could decrease the fat content in cells and effectively inhibit preadipocyte differentiation into adipocyte.

After Oil red $\mathrm{O}$ staining, we observed that both the number and size of fat cells were significantly increased in the 200- and 300- $\mu \mathrm{M}$ nicotinmaide treatments compared to the control. Moreover, the number of bright red fat droplets in adipocytes treated with nicotinamide increased (Fig. 7). After analysis of Oil red $\mathrm{O}$ extraction, it was found that the OD value of the nicotinamide-treated group was higher than control group. Among the treatments, 200- and 300$\mu \mathrm{M}$ of nicotinamide significantly induced the differentiation of preadipocyte into adipocyte compared to control group $(P<0.01)$ (Fig. 8). This showed that nicotinamide increased the TG content in fat cells and stimulated pig preadipocyte differentiation into mature adipocytes.

Analysis of Sirt1, FoxO1, and adipocyte markers in primary pig preadipocytes

To explore the molecular mechanism of compounds that affected Sirt1 function in regulating proliferation and differentiation of pig preadipocytes, we analyzed the expression of Sirt1, target FoxO1 and adipocyte markers with semi-quantitive RT-PCR. Adipocyte genes were PPAR $\gamma 2, \operatorname{CEBP} \alpha, \mathrm{aP} 2$, and LPL. The target gene for Sirt1 was FoxO1. Adipocytes were cultured for $72 \mathrm{~h}$ in medium 
Fig. 7 Effects of nicotinamide on differentiation of pig preadipocyte. Predipocytes were treated with $0 \mu \mathrm{M}, 100 \mu \mathrm{M}$, $300 \mu \mathrm{M}$, and $500 \mu \mathrm{M}$ nicotinamide for 6 days, and then visualized by Oil red $\mathrm{O}$ staining $(\times 200)$. Lipid droplets stained bright red. (A) Control group; (B) $100 \mu \mathrm{M}$ nicotinamide; (C) $300 \mu \mathrm{M}$ nicotinamide; (D) $500 \mu \mathrm{M}$ nicotinamide
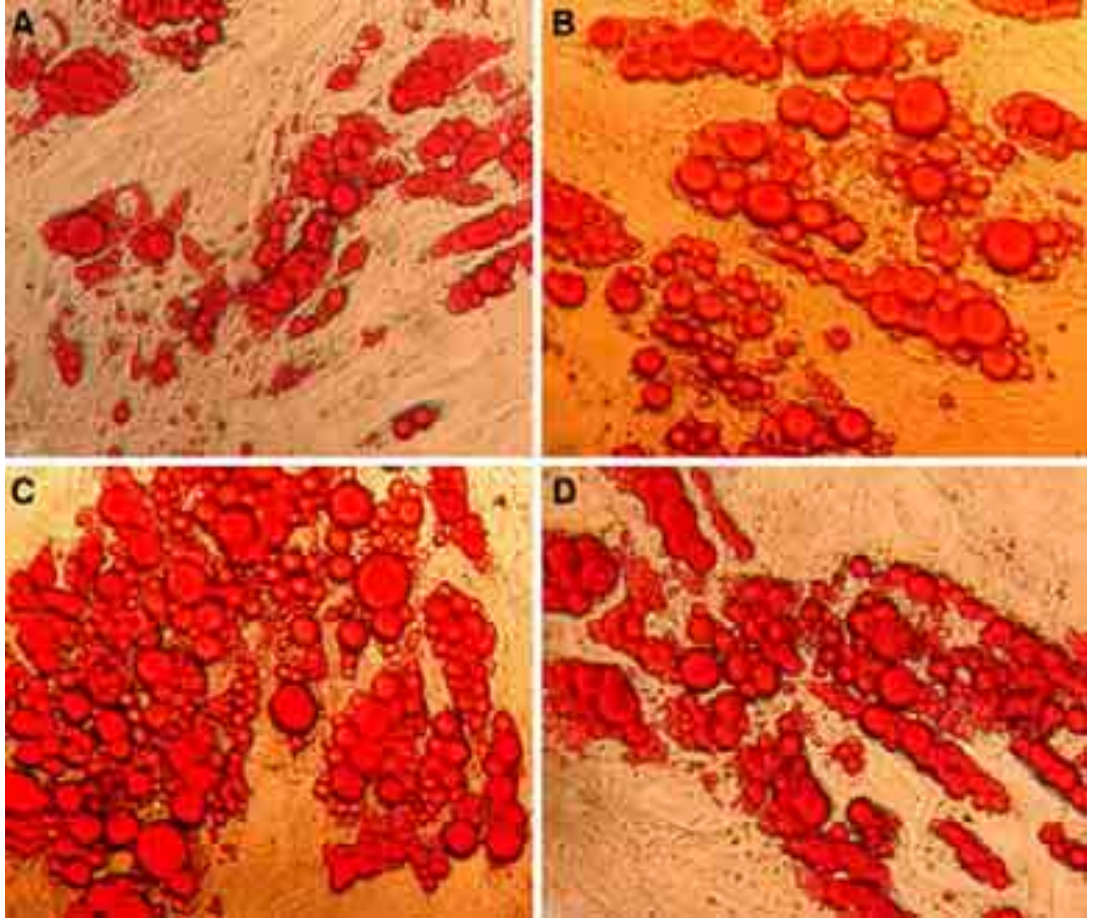

with or without resveratrol and nicotinamide, then total RNA was isolated from the cells and genetic expression was analyzed by RT-PCR. Expression of target and marker genes was normalized to the expression of $\beta$-actin. Adipocytes treated with $100 \mu \mathrm{M}$ resveratrol significantly

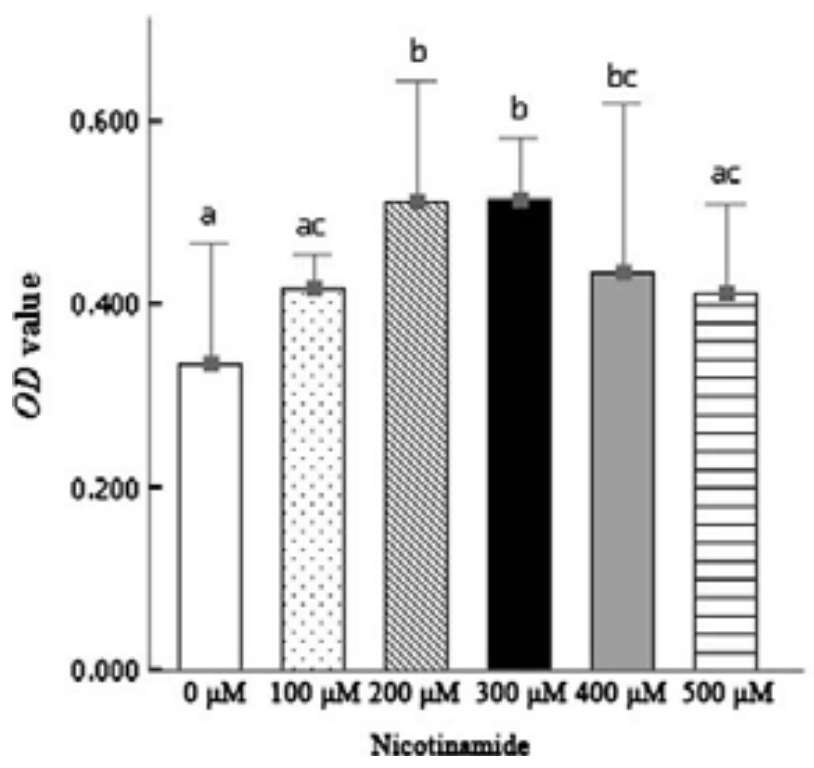

Fig. 8 Differentiation of pig preadipocytes was promoted by nicotinamide. Predipocytes were treated with $0 \mu \mathrm{M}, 100 \mu \mathrm{M}, 200 \mu \mathrm{M}$, $300 \mu \mathrm{M}, 400 \mu \mathrm{M}$, and $500 \mu \mathrm{M}$ nicotinamide for 6 days, and then analyzed by Oil red $\mathrm{O}$ extraction. The results are represented as means \pm S.E. of three independent determinations. Different letters indicate significant differences $(P<0.05)$ activated Sirt 1 mRNA expression $(P<0.01)$, while FoxO1 mRNA expression was significantly diminished compared with the control group $(P<0.01)$. Among adipocytes markers, only the expression of PPAR $\gamma 2$ mRNA was apparently down-regulated $(P<0.01)$. However, the expression of $\mathrm{CEBP} \alpha$, aP2, and LPL mRNA was nearly unchanged (Fig. 9). This hints that Sirt1 may be closely related to PPAR $\gamma 2$. Under stimulation of $300 \mu \mathrm{M}$ nicotinamide, Sirt1 mRNA expression was significantly decreased $(P<0.05)$ compared to control group. Correspondingly, the expression of FoxO1, PPAR $\gamma 2$, and $\mathrm{C} / \mathrm{EBP} \alpha$ mRNA was significantly up-regulated $(P<0.01)$, while aP2 and LPL mRNA expression generally increased $(P<0.05)$ (Fig. 10). This Sirt1-affecting compounds could/might influence the proliferation and differentiation of pig preadipocytes.

\section{Discussion}

Sirtuins are phylogenetically conserved in eukaryotes, prokaryotes, and Archeal species [28]. Sirt1, a member of class I sirtuins, is an $\mathrm{NAD}^{+}$-dependent histone deacetylase first found in humans in 1999 [6, 7]. In addition to histone, Sirt1 has many substrates. FOXO transcription factors might be direct substrates of Sirt1. In mammals, there are four evolutionarily conserved FOXO family members (FOXO1, FOXO3, FOXO4, and FOXO6) that are negatively regulated by the insulin phosphoinositide- 3 kinase (PI3K)-Akt signaling pathway [29-31], among which 

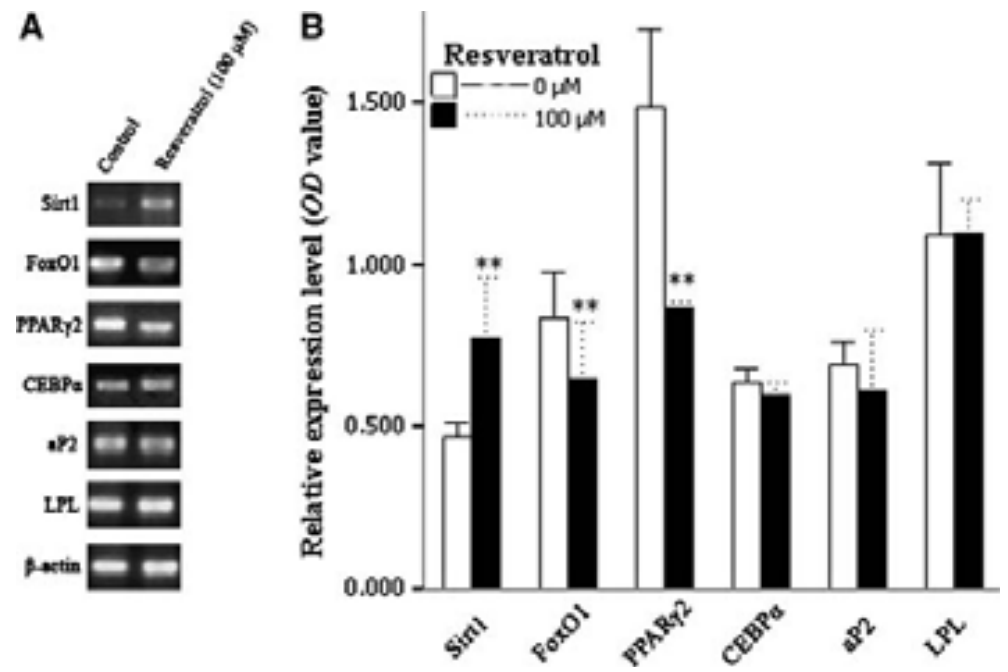

Fig. 9 Up-regulation of Sirt1 mRNA expression and down-regulation of FoxO1 and PPAR $\gamma 2$ mRNA expression by resveratrol. Preadipocytes were cultured with or without $100 \mu \mathrm{M}$ resveratrol for $72 \mathrm{~h}$. Total RNA was isolated and subjected to SQ RT-PCR analysis. (A) Representative ethidium bromide stained gels of target products as well as $\beta$-actin in the same sample. (B) Sirt1, FoxO1, PPAR $\gamma 2$,

$\mathrm{CEBP} \alpha$, aP2, and LPL mRNA abundance assigned as a ratio to $\beta$ actin mRNA. The results are represented as means \pm S.E. of three independent determinations. Single asterisk indicates a statistical difference $(P<0.05)$. Double asterisk indicates a statistical difference $(P<0.01)$
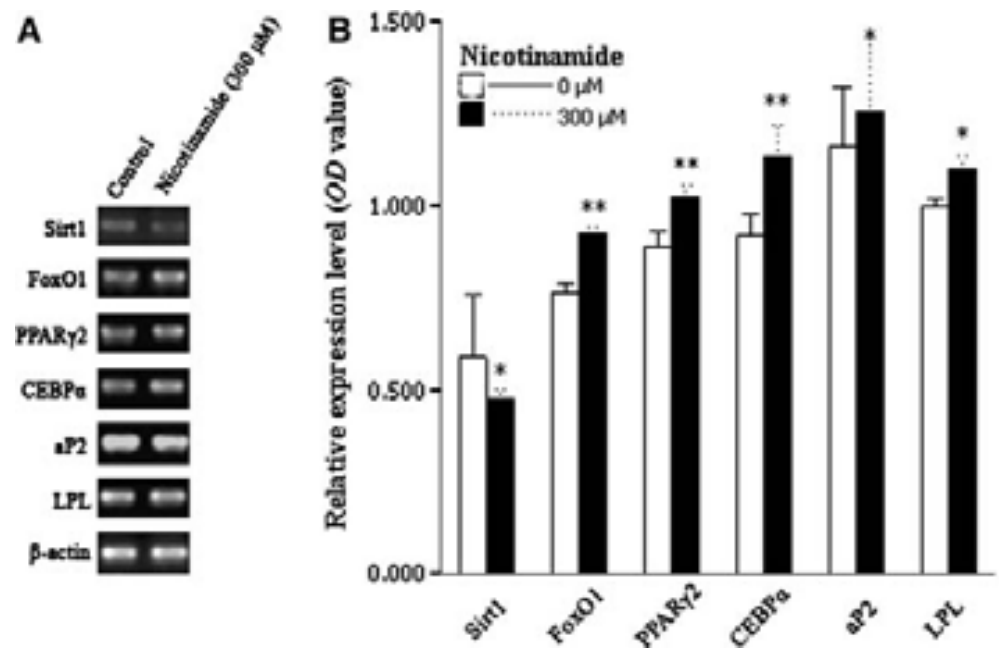

Fig. 10 Down-regulation of Sirt1 mRNA expression and up-regulation of FoxO1, PPAR $\gamma 2, \operatorname{CEBP} \alpha$, aP2, and LPL mRNA expression by nicotinamide. Preadipocytes were treated with or without $300 \mu \mathrm{M}$ nicotinamide for $72 \mathrm{~h}$. Total RNA was isolated and subjected to SQ RT-PCR analysis. (A) Representative ethidium bromide stained gels of target products as well as $\beta$-actin in the same sample. (B) Sirt1,

FOXO1 is closely related to glycolysis, lipogenesis, and insulin action [32-34]. Real-time RT-PCR analysis indicates that Foxol is the most abundant Foxo isoform in murine white and brown adipose tissue [35].

The diversity of substrates is reflected in the various biological activities that SIRTs exert, including development, metabolism, apoptosis, and heterochromatin formation. Sirt1 is widely expressed in fetal and adult tissues, and is especially abundant in early embryogenesis
FoxO1, PPAR $\gamma 2, \operatorname{CEBP} \alpha$, aP2, and LPL mRNA abundance assigned as a ratio to $\beta$-actin mRNA. The results are represented as means \pm S.E. of three independent determinations. Single asterisk indicates a statistical difference $(P<0.05)$. Double asterisk indicates a statistical difference $(P<0.01)$

and germocyte [6]. Cohen et al. reported that compared to expression in ad libitum rats, Sirt1 expression was higher in many tissues of the caloric restricted rats, including brain, visceral fat pads, kidney, and liver tissue [36]. Michishita et al. found through real time PCR that Sirt1 is abundant in human embryonic brain and adult brain tissue [37].

Previous studies have focused on the Sirt1 expression in humans and rats. As a medical animal model, Sirt1 expression in pigs has been rarely reported. The results 
from this study found that Sirt 1 mRNA was widely expressed in multiple pig tissues, including heart, liver, kidney, spleen, skeletal muscle, and adipose tissue. This agrees with studies of other animal species and indicates that Sirt1 was evolutionally conserved in history and may be involved in the regulation of such biological processes as adipogenesis, endocrine signaling, and glucose and lipid metabolism in pigs. The specific mechanism for the regulation of these processes remains to be identified.

Resveratrol (3, 5, 40 -trihydroxystilbene) is a polyphenol compound found in grapes and grape products, such as red wine. It possesses the ability to scavenge oxidativelygenerated free radicals and it exhibits cancer preventative properties [38, 39]. In yeast, resveratrol mimics caloric restriction by stimulating Sir2, increasing DNA stability and extending lifespan by $70 \%$ [27]. In mammals, resveratrol can enhance Sirt1-dependent cellular processes such as axonal protection [40], fat mobilization [16], and inhibition of NF- $\kappa \mathrm{B}$-dependent transcription [41]. It increases Sirt1 activity by as much as 8-fold, lowering the $\mathrm{Km}$ value for acetylated substrate and to a much lesser extent that of NAD [27]. Dose-response experiments showed that resveratrol doubled the rate of deacetylation by Sirt1 at about $11 \mu \mathrm{M}$ and was saturated at $100-200 \mu \mathrm{M}$ [27]. In this study, resveratrol was chosen as an activator of Sirt1 in pig adipocytes. It was found that resveratrol could significantly increase the expression of Sirt1 mRNA as measured by RT-PCR. Moreover, analysis of MTT and Oil red $\mathrm{O}$ extraction showed that $100 \mu \mathrm{M}$ resveratrol greatly inhibited proliferation and differentiation of pig preadipocytes. Thus, we used $100 \mu \mathrm{M}$ of resveratrol as the optimal concentration.

Nicotinamide, a form of vitamin B3 [42] and a product of sirtuin catalyzed deacetylation, is a strong noncompetitive inhibitor of yeast Sir2 and human Sirt1 activity, both in vitro and in vivo [43]. The degree of inhibition by nicotinamide (IC50 $<50 \mu \mathrm{M}$ ) is equal to or better than the most effective known synthetic inhibitors of this class of proteins [43]. High doses of nicotinamide and its acid derivative, nicotinic acid, are often used interchangeably to self-treat a number of conditions including anxiety, osteoarthritis, psychosis, cancer, and type I diabetes [44]. We found that nicotinamide significantly promoted pig preadipocyte proliferation and differentiation. The optimal concentration of nicotinamide was $300 \mu \mathrm{M}$. Otonkoski et al. found that nicotinamide induces human fetal islet cell differentiation and mature [45]. Vaca et al. reported that nicotinamide induces both proliferation and differentiation of embryonic stem cells into insulin-producing cells [46]. This shows that in living organisms nincotinamide has multiple roles of which the molecular mechanisms remain unknown.

Preadipocytes are derived from adipose tissue-derived stem cells (ADSCs). Adipocyte differentiation in vitro systems using various preadipose cell lines and primary preadipocytes shows that a dissection of the molecular and cellular events takes place during the transition from undifferentiated fibroblast-like preadipocytes into a mature round fat cell. This process includes four stages: growth arrest; clonal expansion; early change in gene expression; late events and terminal differentiation [47]. As with primary human, mouse and rat preadipocyte and cell lines, primary pig preadipocytes also went through proliferation and differentiation into adipocytes with lipid droplets in vitro. It has been demonstrated that $\operatorname{PPAR} \gamma 2, \mathrm{C} / \mathrm{EBP} \alpha, \mathrm{aP} 2$, and LPL all are prominent adipocyte marker genes. Among them, PPAR $\gamma 2$ and $\mathrm{C} / \mathrm{EBP} \alpha$ play a key role in the complex transcriptional cascade during adipogenesis, and have been shown to regulate, directly or indirectly, the gene expression necessary for the development of mature adipocytes [1].

Sirt1 mRNA was found to be widely expressed throughout the entire differentiation process of pig preadipocytes, and abundant in middle term after adipocyte differentiation. Furthermore, compounds affecting Sirt1 activation significantly influenced pig preadipocyte proliferation and differentiation. This suggests that Sirt1 plays an important role during pig adipocyte development. However, the molecular mechanism for the regulation of pig preadipocyte development by Sirt1 is unclear. Sirt1 represses skeletal muscle differentiation by down-regulating the expression of muscle transcriptional regulators, such as MyoD and MEF2 in C2C12 cell lines and human primary skeletal muscle [11]. Picard et al. pointed out that Sirt1 promoted fat mobilization in fully differentiated adipocytes and also attenuated development of adipocytes from preadipocytes in 3T3-L1 adipocytes, which might be by repressing PPAR- $\gamma$ by docking with its cofactors NCoR and SMRT [16]. Likewise, we found that the expression of Sirt1 mRNA in pig preadipocytes increased significantly while FoxO 1 and PPAR $\gamma 2$ mRNA notably decreased after treatment with $100 \mu \mathrm{M}$ of resveratrol for $72 \mathrm{~h}$. After treatment with $300 \mu \mathrm{M}$ of nicotinamide, expression of Sirt1 mRNA decreased significantly while FoxO1 and adipocyte genes PPAR $\gamma 2, \mathrm{C} / \mathrm{EBP} \alpha, \mathrm{aP} 2$, and LPL mRNA increased. This implied that modulation of Sirt1 activity on pig preadipocyte development is closely related to adipocyte specific genes and target FoxO1. Previous research demonstrated that Sirt1 has a close relationship with FOXO, a transcription factor that is downstream of the IGF signaling system. Sirt1 binds and deacetylates FOXO, and mediates FOXO-induced transcription in mammalian cells. FOXO has a feedback effect on Sirt1 activity [48]. Meanwhile, FoxO1 plays an important role during adipocyte development. Nakae et al. demonstrated that Foxo1 functions in adipose cells to couple insulin signaling to adipogenesis, which involves switching preadipocytes from 
proliferation to terminal differentiation [35]. Armoni et al. indicated that repression of PPAR $\gamma 2$ gene promoters by FOXO1 leads to GLUT4 up-regulation, subsequently resulting in enhanced glucose transport and cellular insulin sensitivity in primary rat adipocytes [49]. It has been shown that Sirt1 stimulates IGFBP-1 promoter activity through FoxO-dependent mechanisms in HEK293 cells [50]. The loss of Sirt1 protein in mice results in increased expression of the IGF binding protein IGFBP1, a secreted modulator of IGF function [51]. Han et al. showed that Sirt1 controls self-renewal and proliferation of mouse embryonic stem cells by regulation of p53 localization through deacetylation of p53 [52]. Long-term inhibition of Sirt1 by Sirt1 siRNA reduced cell proliferation rate, whereas long-term overexpression of Sirt1 by a retroviral vector containing Sirt1 gene enhanced cell proliferation [52]. The findings are contrary to our results and might be related to differences in cell types or species.

In summary, we conclude that activation of Sirt1 can down-regulate the proliferation and differentiation of pig preadipocytes. Furthermore, we speculate that Sirt1 regulation of pig preadipocyte proliferation and differentiation might be through one of two mechanisms. First, since Sirt1 mRNA expression is increased by resveratrol and decreased by nicotinamide, we hypothesize that Sirt1 may directly control the expression of adipocyte marker genes, leading to adipocyte development in pigs. Second, since FoxO1 modulates self-expression, or target gene PEPCK and IGFBPs, and adipocyte genes PPAR $\gamma 2$ to affect the adipocyte proliferation and differentiation, we suggest that Sirt1 may indirectly modulate the proliferation and differentiation of pig preadipocytes through its effect on the FoxO1 or FoxO1 target gene. The profound studies on the role of Sirt1 in pig adipogenesis will be explored in future work.

Acknowledgments This research was sponsored by National Basic Research Program of China (2004CB117506). We thank Dr. Z. Y. Zhang (Gemin X Company, Canada) and Dr. J. Gale (Northwest A\&F University) for their suggestions and correction of the English manuscript.

\section{References}

1. Morrison RF, Farmer SR (2000) Hormonal signaling and transcriptional control of adipocyte differentiation. J Nutr 130:3116S-3121S

2. Gregoire FM (2001) Adipocyte differentiation: from fibroblast to endocrine cell. Exp Biol Med 226:997-1002

3. Fe've B (2005) Adipogenesis: cellular and molecular aspects. Best Pract Res Clin Endocrinol Metab 19:483-499

4. Imai SI, Armstrong CM, Kaeberlein M et al (2000) Transcriptional silencing and longevity protein Sir2 is an NAD-dependent histone deacetylase. Nature 403:795-800
5. Smith JS, Brachmann CB, Celic I et al (2000) A phylogenetically conserved NAD+-dependent protein deacetylase activity in the Sir2. Proc Natl Acad Sci USA 97:6658-6663

6. Frye RA (1999) Characterization of five human cDNAs with homology to the yeast SIR2 gene: Sir2-like proteins (sirtuins) metabolize NAD and may have protein ADP-Ribosyltransferase activity. Biochem Biophys Res Commun 260:273-279

7. Frye RA (2000) Phylogenetic classification of prokaryotic and eukaryotic Sir2-like proteins. Biochem Biophys Res Commun 273:793-798

8. Sherman JM, Stone EM, Freeman-Cook LL et al (1999) The conserved core of a human SIR2 homologue functions in yeast silencing. Mol Biol Cell 10:3045-3059

9. Motta MC, Divecha N, Lemieux M et al (2004) Mammalian SIRT1 represses Forkhead transcription factors. Cell 116:551563

10. Brunet A, Sweeney LB, Sturgill JF et al (2004) Stress-dependent regulation of FOXO transcription factors by the SIRT1 deacetylase. Science 303:2011-2015

11. Fulco M, Schiltz RL, Iezzi S et al (2003) Sir2 regulates skeletal muscle differentiation as a potential sensor of the redox state. Mol Cell 12:51-62

12. Luo J, Nikolaev AY, Imai S et al (2001) Negative control of p53 by Sir $2 \alpha$ promotes cell survival under stress. Cell 107:137-148

13. Vaziri H, Dessain SK, Eaton EN et al (2001) hSIR2 ${ }^{\text {SIRT1 }}$ functions as an NAD-dependent p53 deacetylase. Cell 107:149-159

14. Rodgers JT, Lerin C, Haas W et al (2005) Nutrient control of glucose homeostasis through a complex of PGC-1a and SIRT1. Nature 434:113-118

15. McBurney MW, Yang XF, Jardine K et al (2003) The mammalian SIR $2 \alpha$ protein has a role in embryogenesis and gametogenesis. Mol Cell Biol 23:38-54

16. Picard F, Kurtev M, Chung NJ et al (2004) Sirt1 promotes fat mobilization in white adipocytes by repressing PPAR- $\gamma$. Nature 429:771-776

17. Bäckesjö CM, Li Y, Lindgren U et al (2006) Activation of Sirt1 decreases adipocyte formation during osteoblast differentiation of mesenchymal stem cells. J Bone Miner Res 21:993-1002

18. Picard F, Guarente L (2005) Molecular links between aging and adipose tissue. Int J Obesity 29: S36-S39

19. Bordone L, Motta MC, Picard F et al (2006) Sirt1 regulates insulin secretion by repressing UCP2 in pancreatic $\beta$ cells. PLoS Biol 4:210-220

20. Lagouge M, Argmann C, Gerhart-Hines $Z$ et al (2006) Resveratrol improves mitochondrial function and protects against metabolic disease by activating SIRT1 and PGC-1alpha. Cell 127:1109-1122

21. Baur JA, Pearson KJ, Price NL et al (2006) Resveratrol improves health and survival of mice on a high-calorie diet. Nature 444:337-342

22. Gianfranco B, Alfredo C (2004) Metabolic and cardiovascular disorders in highly inbred lines for intensive pig farming: how animal welfare evaluation could improve the basic knowledge of human obesity. Ann 1st Super Sanita 40:241-244

23. Belliger DA, Merrichks EP, Nichols TC (2006) Swine models of type 2 diabetes mellitus: insulin resistance, glucose tolerance, and cardiovascular complications. ILAR J 47:243-258

24. Larsen MO, Rolin B (2004) Use of the Göttingen minipig as a model of diabetes, with special focus on type 1 diabetes research. ILAR J 45:303-313

25. Fernandez ML (2001) Guinea pigs as models for cholesterol and lipoprotein metabolism. J Nutr 131:10-20

26. Vodicka P, Smetana K, Dvoránková B et al (2005) The miniature pig as an animal model in biomedical research. N Y Acad Sci 1049:161-171 
27. Howitz KT, Bitterman KJ, Cohen HY et al (2003) Small molecule activators of sirtuins extend Saccharomyces cerevisiae lifespan. Nature 425:191-196

28. Buck SW, Gallo CM, Smith JS (2004) Diversity in the Sir2 family of protein deacetylases. J Leukocyte Biol 75:939-950

29. Brunet A, Bonni A, Zigmond MJ et al (1999) Akt promotes cell survival by phosphorylating and inhibiting a Forkhead transcription factor. Cell 96:857-868

30. Kops GJ, Ruiter ND, Vries-Smits AM et al (1999) Direct control of the Forkhead transcription factor AFX by protein kinase B. Nature 398:630-634

31. Jacobs FMJ, Heide LP, Wijchers PJEC et al (2003) FoxO6, a novel member of the FoxO class of transcription factors with distinct shuttling dynamics. J Biol Chem 278:35959-35967

32. Nakae J, Biggs WH, Kitamura $T$ et al (2002) Regulation of insulin action and pancreatic $\beta$-cell function by mutated alleles of the gene encoding Forkhead transcription factor foxo1. Nat Genet 32:245-253

33. Altomonte J, Cong L, Harbaran S et al (2004) Foxo1 mediates insulin action on apoC-III and triglyceride metabolism. J Clin Invest 114:1493-1503

34. Zhang WW, Patil S, Chauhan B et al (2006) FoxO1 regulates multiple metabolic pathways in the liver. J Biol Chem 281:10105-10117

35. Nakae J, Kitamura T, Kitamura Y et al (2003) The Forkhead transcription factor foxo1 regulates adipocyte differentiation. Dev Cell 4:119-129

36. Cohen HY, Miller C, Bitterman KJ et al (2004) Calorie restriction promotes mammalian cell survival by inducing the SIRT1 deacetylase. Science 305:390-392

37. Michishita E, Park JY, Burneskis JM et al (2005) Evolutionarily conserved and nonconserved cellular localizations and functions of human SIRT proteins. Mol Biol Cell 16:4623-4635

38. Fang JG, Lu M, Chen $\mathrm{ZH}$ et al (2002) Antioxidant effects of resveratrol and its analogues against the free-radical-induced peroxidation of linoleic acid in micelles. Chemistry 8:4191-4198

39. Ray PS, Maulik G, Cordis GA et al (1999) The red wine antioxidant resveratrol protects isolated rat hearts from ischemia reperfusion injury. Free Radic Biol Med 27:160-169
40. Araki T, Sasaki Y, Milbrandt J (2004) Increased nuclear NAD biosynthesis and SIRT1 activation prevent axonal degeneration. Science 305:1010-1013

41. Yeung F, Hoberg JE, Ramsey CS et al (2004) Modulation of $\mathrm{NF}-\kappa \mathrm{B}$-dependent transcription and cell survival by the SIRT1 deacetylase. EMBO J 23:2369-2380

42. Dietrich L S (1971) Regulation of nicotinamide metabolism. Am J Clin Nutr 24:800-804

43. Bitterman KJ, Anderson RM, Cohen HY et al (2002) Inhibition of silencing and accelerated aging by nicotinamide, a putative negative regulator of yeast Sir2 and human SIRT1. J Biol Chem 277:45099-45107

44. Kaanders JH, Pop LA, Marres HA et al (2002) ARCON: experience in 215 patients with advanced head-and-neck cancer. Int $\mathbf{J}$ Radiat Oncol Biol Phys 52:769-778

45. Otonkoski T, Beattie GM, Mally MI et al (1993) Nicotinamide is a potent inducer of endocrine differentiation in cultured human fetal pancreatic cells. J Clin Invest 92:1459-1466

46. Vaca P, Berna G, Martín F et al (2003) Nicotinamide induces both proliferation and differentiation of embryonic stem cells into insulin-producing cells. Transplant Proc 35:2021-2023

47. Gregoire FM, Smas CM, Sul HS (1998) Understanding adipocyte differentiation. Physiol Rev 78:783-809

48. Giannakou M E, Partridge L (2004) The interaction between FOXO and SIRT1: tipping the balance towards survival. TRENDS Cell Biol 14:408-412

49. Armoni M, Harel C, Karni S et al (2006) FOXO1 represses peroxisome proliferator-activated receptor- $\gamma 1$ and $-\gamma 2$ gene promoters in primary adipocytes: a novel paradigm to increase insulin sensitivity. J Biol Chem 281:19881-19891

50. Gan LX, Han YS, Bastianett S et al (2005) FoxO-dependent and independent mechanisms mediate SirT1 effects on IGFBP-1 gene expression. Biochem Biophys Res Commun 337:1092-1096

51. Lemieux ME, Yang X, Jardine K et al (2005) The Sirt1 deacetylase modulates the insulin-like growth factor signaling pathway in mammals. Mech Ageing Dev 126:1097-1105

52. Han MK, Mantel C, Guo Y et al (2005) Role of SIRT1 in proliferation and self-renewal of mouse embryonic stem cells. Proc Soc Exper Biol Med 106:520 